\title{
PHOTOGRAPHS FROM AN EXCURSION TO NORTH AFRICA IN 1936
}

\author{
Jan Šejbl $1^{1}$
}

\begin{abstract}
The ethnographic photographic collection of the Náprstek Museum has two sets of photographic material documenting an excursion to North Africa, which was organized mainly for teachers in 1936 by the Excursion Department of the Central Association of Teachers in the Moravian-Silesian Lands. The main destinations of the excursion were Morocco, Algeria, and Tunisia. In 1961, the Náprstek Museum received a set of postcards which was collected by the writer Sida Volfová during the excursion. In the 1970s, teacher Karel Kř́žzek donated three photo albums and loose photographs which he took during the excursion to the museum. Together with other preserved documents, it was possible to accurately reconstruct the course of the excursion and evaluate everything from both a geographic and thematic perspective.
\end{abstract}

KEYWORDS: Tourist photography - North Africa - Morocco - Algeria - Tunisia - Sida Volfová - Karel Křížek - Jarmila Vajglová - EXOD

\section{Introduction}

With the development of photographic technology since the end of the 19th century, taking photographs has become more accessible to an ever-widening circle of people. Along with the development of transport, the number of photographers and tourists has continued to increase. This has enabled the creation of a whole new branch of industry which provides suitable photographic equipment and film, as well as services related to its processing. ${ }^{2}$

Unlike well-known travelers who received publicity and whose photographs were printed in magazines, books, or exhibited during lectures, tourist photography was usually only for personal use or for immediate family and friends. Only when tourist photographs become part of the collections of specialized institutions - museums and archives - do their roles change. They become a source of information that can be scientifically researched and published in an appropriate manner.

In this study, we will focus on a set of photographs from an excursion to North Africa that took place in 1936. The set is kept in the ethnographic photographic collection of the Náprstek Museum of Asian, African and American Cultures, which is an organizational unit of the National Museum in Prague. Between 1973 and 1977, one of the participants in the excursion, a teacher named Karel Křrižek from Kladno,

1 Contact: Jan Šejbl, National Museum - Náprstek Museum of Asian, African and American Cultures, Prague, Czech Republic; e-mail: jan.sejbl@nm.cz. This work was financially supported by the Ministry of Culture of the Czech Republic (DKRVO 2019-2023/19.III.b, 00023272).

2 de Avelar Pinheiro, 2008, p. 1398. 
donated three large photograph albums, over three hundred loose photographs, and several other documents to the Náprstek Museum. In addition to the original itinerary for the participants of the excursion [Pl. 1], these documents included a travel journal of another participant of the excursion, high school teacher Jarmila Vajglová from Plzeň.

Another participant in the excursion, the writer Sida Volfová, published her impressions of the excursion in a newspaper. Between 31 August and 26 November 1936, a total of thirteen of her feuilletons ${ }^{3}$ were published in the Večerník národní listy newspaper. Postcards from the estate of Sida Volfová are stored in the Náprstek Museum, which were handed over to the museum in 1962 by a notary in Náchod, where the writer lived.

\section{EXOD}

The Excursion Department of the Central Association of Teachers' Unions in Moravia (Exkursní odbor Ústředního spolku učitelských jednot na Moravě, abbreviated as EXOD) was established in Brno in 1928. Selected school principals and teachers were entrusted with its organization and management. The aim was to organize tours for teachers, their family members, and friends. The purpose of the excursions was primarily educational. Through the authentic experiences gained from the places they visited, teachers were to teach better and more interestingly. However, recreation was not neglected either. Swimming and hiking were also included in the itinerary of sightseeing tours. Some organized tours were directly conceived as residential, in the mountains, or by the sea. The dates of the tours mostly fell into the period of summer or spring holidays.

The offer of tours was highly varied. In 1936, when EXOD organized an excursion to North Africa, the catalogue of offers contained various domestic and foreign tours. Domestic tours covered the entire territory of Czechoslovakia. Foreign tours were mainly in Europe: the former Yugoslavia, Bulgaria, Spain, Greece, Austria, Hungary, the Netherlands, Switzerland, Italy, Great Britain, Norway, and the Soviet Union. The longest and most expensive of the offers was a 'large, combined excursion by bus and ocean liner to North Africa' which we will discuss in more detail. ${ }^{5}$

EXOD operated until 1938. After the disintegration of Czechoslovakia and the German occupation of the Czech lands, its activities were banned. During World War II, some EXOD officials also fell victim to Nazi persecution. At the end of the war, most of the documents related to the pre-war activities of the Excursion Department were destroyed during a fire. ${ }^{6}$ In April 1946, the activities of the Excursion Department in Brno resumed thanks to the initiative of the teachers themselves. It mainly focused on educational walks.

Political changes in Czechoslovakia after 1948 were reflected in the activities of EXOD. In 1953, the organization was taken over by the Central Committee of the Trade Union of Education and Science Workers (Ústřední výbor odborového svazu pracovníků školství a vědy). Emphasis was still placed on the political and educational

3 Some feuilletons were divided into two numbers; see Volfová, 1936a-m.

4 Bulínová and Hořčičková, 1971, p. 10.

5 Kam pojedete letos? Jed'te s námi! 1936, p. XIVm.

6 Moravian Regional Archive, Collection of the Central Association of Teachers' Unions in the MoravianSilesian Lands. Information on the destruction of the archive was obtained during a personal visit to the Moravian Provincial Archive in Brno on 10 June 2019. 
dimension of the events with regard to the current ties of Czechoslovakia within the so-called Eastern Bloc. 'Outposts' were set up all over the country to work together to prepare excursions and stays. Gradually, they specialized in a certain subject, such as literary, historical, or natural sciences. In cooperation with travel agencies, foreign trips to friendly countries were also organized. The interest from teachers far exceeded the offer. In 1966, in addition to domestic outposts and tours, thirty-three foreign tours were organized. ${ }^{7}$

After the fall of the communist regime in 1989, the future of EXOD seemed uncertain. However, thanks to the enthusiasm of the teachers involved, its activities were continued. The focus of the activities returned with a combination of education and recreation. Despite deliberations about transforming into a commercial entity, EXOD remained a non-profit organization under the administration of the Czech-Moravian Trade Union of Education Workers (Českomoravský odborový svaz pracovníků ve školstvî). ${ }^{8}$ In 1995, the abbreviation EXOD was registered as a trademark. The tradition, founded in 1928, continues to this very day.

\section{Excursion to North Africa}

Excursions to North Africa appeared in EXOD's offer as early as 1935. At that time, there was an excursion labelled 'Morocco' from 30 June to 26 July 1935. The route was shorter, only leading from Marseille to Morocco and Algeria: from Marseille to the port of Oran. ${ }^{9}$ In 1936, the route was extended to include Tunisia. According to the surviving instructions for the participants of the excursion, ${ }^{10}$ the original plan provided for the fastest possible journey from Czechoslovakia to the Mediterranean Sea, from where it was to continue to Tunisia and further through Morocco to Algeria. However, the journey eventually went in the opposite direction, due to better shipping connections between Tunisia and Marseille. The way to the sea itself was also extended by a number of stops to make it more interesting. The duration of the excursion was thirty-six days, from 30 June to 4 August 1936. It was the most expensive excursion from EXOD's offer for the 1936 season. The catalogue price was 5,460 Czechoslovak Crowns (CSK) ${ }^{11}$, while the final price according to the preserved instructions for participants was 5,500 CSK.

We could call the excursion 'all inclusive' in modern-day terms. The price included bus and boat transport, accommodation, and meals during the whole trip, including drinks and wine, gratuities, admission to the African continent and basic insurance for the bus and its passengers. Those interested could pay extra for a higher class on the boat passage, which was third class for the basic price, and also individual insurance. The main means of transport was a small bus operated by travel agency 'Sportingcary Praha'. It was a dual-axle Citroën C6G1 with a capacity for twenty-three people, including the driver. ${ }^{12}$ The roof of the bus could be opened. Participants' luggage was

\footnotetext{
7 Beran, 2013, p. 3.

8 Beran, 2013, p. 3.

9 Program cest Exkursního odboru Ústředního spolku jednot učitelských v zemi Moravskoslezské, 1934, p III

10 National Museum - Náprstek Museum, register of originators, Kř́žžek Karel folder, Instructions for participants on a bus tour to Africa in 1936.

11 Kam pojedete letos? Jed'te s námi! 1936, p. XIVm.

12 Gruhier 2019 p. 2.
} 
transported on a roof rack. Due to the capacity, each participant was allowed only one piece of luggage with the maximum dimensions of $65 \times 45 \times 22 \mathrm{~cm}$.

The capacity of the excursion was limited to twenty participants. The list of names has not been preserved, so information about specific people is revealed through preserved documents or captions in photographs. The owner of the bus was Mr. Aleš Šterrba, who personally participated in the excursion as a driver along with the codriver Mr. Kozák. The leader of the excursion was Jan Peč, a professional teacher from Prague [Pl. 2].

Due to the photo albums, we know about Karel Kř́źžek, a teacher from Kladno. A travel journal handed over by Karel Křížek was written by Jarmila Vajglová, a high school French teacher from Plzeň. In the journal, Mrs. Vajglová specifically mentions Mrs. Volfová, Mr. Štěrba, the leader of the expedition Jan Peč, and Dr. Matoušková. ${ }^{13}$ The writer Sida Volfová from Náchod published her observations in newspaper feuilletons. They mention Dr. Jerman. ${ }^{14}$ The captions in the photographs, in addition to the several people mentioned above, also identify Dr. Jermanová, Dr. Pech, ${ }^{15}$ and the school principal Marie Dobiášová from Brno. ${ }^{16}$

The excursion began in Prague on 30 June 1936, at 5:30 am [Pl. 3]. The bus went to Plzeň, which was the second boarding point. Jarmila Vajglová, the author of the unpublished travel journal, also boarded there. Sida Volfová later noticed how comfortable the bus was and how each participant had good view:

We settled into our separate chairs, cleverly in a comfortable coach built so that we never blocked each other's view; moreover, every day we all moved up a row, while who sat at the window came to the centre, and the next day returned to the window. ${ }^{17}$

The bus then headed for the border with Germany. The expedition reached GarmischPartenkirchen, via Munich, where the first accommodation was located. The next day, the journey continued across the Alps to Switzerland. The narrow mountain roads were difficult for the bus to cross. There was even a minor traffic accident during the climb to St. Moritz Pass near the village Schuls. A collision with a lorry shattered one of the bus windows and one participant was slightly injured. ${ }^{18}$ Fortunately, everything was resolved on the spot.

The journey continued on towards the Swiss-Italian border and to the city of Milan. After an overnight stay and a short sightseeing tour of the city, the journey continued to the Mediterranean coast and a crossing with several stops until they reached Monte Carlo. It was not until 3 July that the expedition arrived at the French port of Marseille [Fig. 1].

The following day, the participants of the expedition and both drivers boarded the ship Chella from the French company Compagnie de Navigaton Paquet. The bus was

13 National Museum - Náprstek Museum, register of originators, Kř́ižek Karel folder, Journey by Bus to Africa journal, no page numbering.

14 Volfová 1936a, p. 4.

15 Dr. Jermanová and Dr. Pech are named on two photos inserted into the third album.

16 National Museum - Náprstek Museum, ethnographic photographic collection, Inv. No. Af III 913.

17 Volfová 1936a, p. 4.

18 Only Jarmila Vajglová mentions the accident in her notes. 


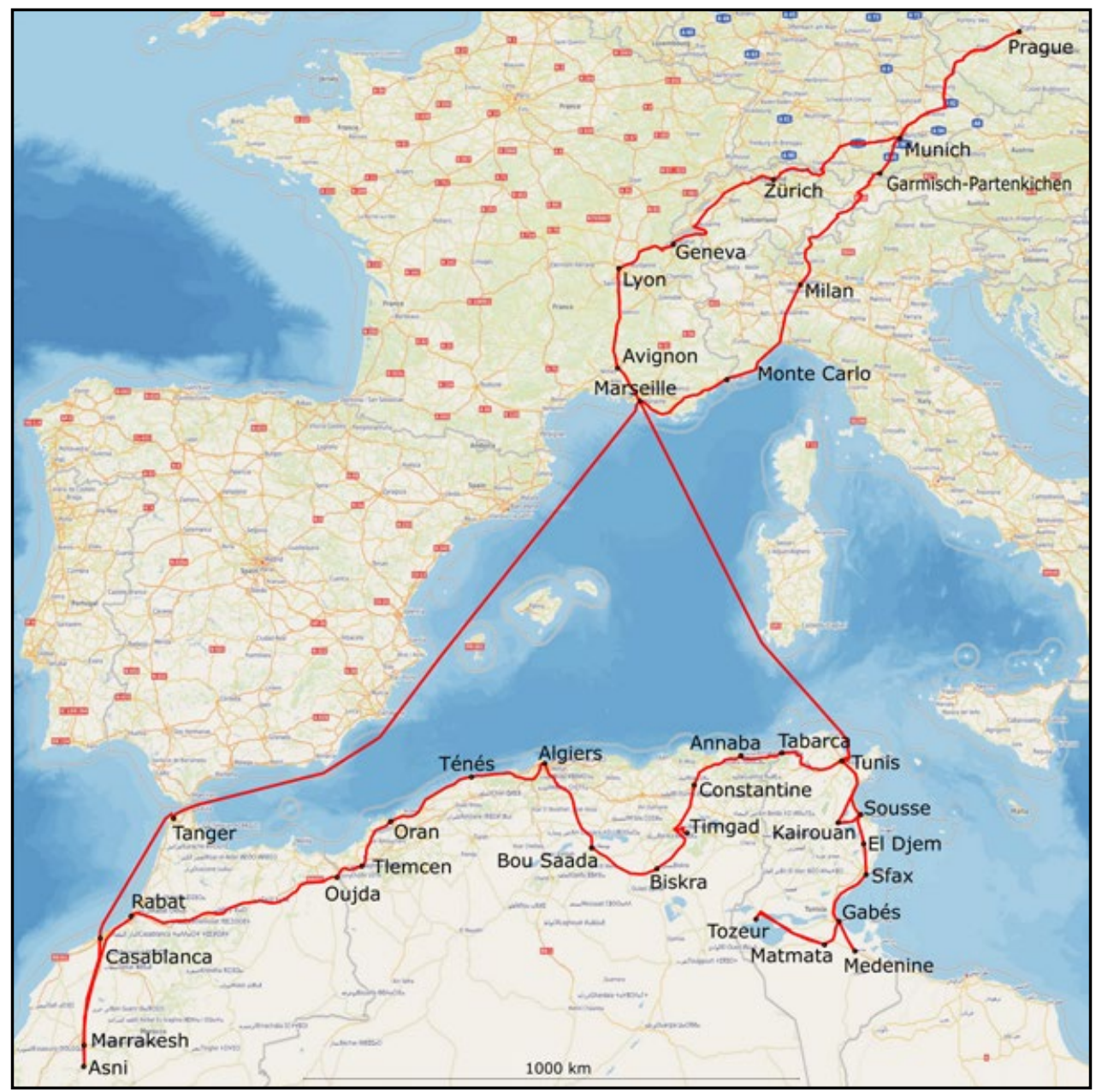

Fig. 1. Route of the excursion to North Africa from 30 June to 4 August.

also loaded onto the ship. The passengers spent two nights on board the ship. After sailing along the French and Spanish coasts, the ship passed through the Strait of Gibraltar. The voyage was complicated by thick fog and cold weather.

Early on the morning of 6 July, the ship docked briefly in the Moroccan port of Tangier, but the passengers could not leave the ship, and only cargo was unloaded. That evening, the ship arrived in the Moroccan port of Casablanca, which was the starting point for their further journey across the mainland.

The first part of the journey led south to the city of Marrakesh and the village of Asni at the foot of the High Atlas. A tour of Casablanca followed after their return on 10 July. Interest was focused mainly on historical monuments, but refreshment was also available from traditional cafes and swimming in pools by the sea. From Casablanca, the expedition continued along the coast north to the port of Rabat. 11 July was entirely devoted to a tour of the city and Moorish as well as ancient monuments in nearby Chellah. 
The next day, the road led inland through Meknes and Volubilis to the city of Fes. Here, the tourists spent the whole of 13 July sightseeing historical monuments and visiting the markets. The next day, the bus headed east again. Lunch was enjoyed in Taourirt and dinner in Oujda near the border with Algeria.

On 15 July, the bus with the expedition crossed the border of Algeria. The first stop was Tlemcen further inland, and accommodation was provided in the port of Oran. The next day, the journey continued along the Mediterranean coast to the resort of Tenés, where swimming in the sea was also on the agenda. On 17 July, the expedition visited ancient monuments in Cherchell, and via Chiffa and Blida arrived in the city of Algiers. The whole next day was reserved for sightseeing around the city.

From Algeria, the expedition headed across the mountain range inland to the edge of the Sahara. The excursion to Bou Saada was complicated by two flat tires. In Biskra, which was another stop on the way, a camel ride was prepared for the participants of the excursion. They returned by horse-drawn tram. During the transfer to the city of Constantine, the expedition visited the remains of the ancient city of Timgad. The route was heading back to the coast. On 22 July, the bus arrived in the port of Bone, and the next day the expedition crossed the Tunisian border.

The starting point of the journey through Tunisia was the capital Tunis. From there, the expedition took a three-day trip south, during which they visited Kairouan, El Djem, Sfax, and Gabes. In the town of Matmata they were able to see the rock dwellings of the Berbers. On 28 July, the expedition returned to Tunisia. Two whole days were set aside for sightseeing there. The participants visited monuments, including the Bardo Palace, and a museum. They took an electric train to the ruins of the ancient city of Carthage. On the morning of 30 July, the expedition along with the bus boarded the steamer $E l$ Biar, which was destined for the French port of Marseille.

The voyage to Marseille was complicated by stormy seas. The ship did not arrive at port until the evening of 31 July. The return journey first led to the historic French cities of Avignon and Lyon, where accommodation was provided. On 2 August, the expedition headed from Lyon to the Swiss border, and further to Lake Geneva. After stops in Geneva and Lausanne, further accommodation was provided in the town of Solothurn. The next day followed with a crossing through Zurich and Winthertur to Lake Constance, and further to the German border.

The last night before returning was spent in Munich. On 4 August, the expedition returned to Czechoslovakia via Landshut and Furth im Wald. The first stop in the Czech lands was Domažlice, where participants had lunch. Shortly afterwards, Dr. Matoušková disembarked in Staňkov. Another three participants, including Jarmila Vajglová, got out in Plzen. ${ }^{19}$ The remaining participants ended their excursion in Prague.

\section{Preserved pictorial material from the excursion}

There are two sets of photographs from the excursion to North Africa in 1936 preserved in the Náprstek Museum. The owner of the largest set of was Karel Kř́žek, a teacher from Kladno. The photographic material he donated to the museum consists of three photographic albums and loose photographs. He gradually handed them over to the

19 National Museum - Náprstek Museum, registry of authors, Kř́žzek Karel folder, Journey by Bus to Africa journal, no page numbering. 
Náprstek Museum along with several documents between 1973 and 1977. The documents are stored in the register of the originators of the collections of the Náprstek Museum, and the photographs were entered in the ethnographic photographic collection of the Náprstek Museum.

The three hardcover albums have a format of $40 \times 29.5 \mathrm{~cm}$. Colored cardboard and white sheets alternate inside them. The white sheets were originally only supposed to have a protective function, but later the photographs were glued to them as well. These are mainly duplicates of images pasted onto the colored cardboard. The first album titled 'Bus to North Africa I. Morocco' contains 181 bound sheets, onto which 322 photographs are pasted [Pl. 4]. The second album titled 'Bus to North Africa I. Morocco Part 2' contains 47 bound sheets and 90 photographs [Pl. 5]. The third album titled 'Bus to North Africa II. Algeria and Tunisia' contains 204 bound sheets and 97 photographs [Pl. 6]. In addition to the photographs, stickers from visited hotels are also affixed to several places in the albums [Pl. 7]. The albums are complemented by 327 loose photographs.

Most of the photographs that are pasted in albums are enlargements measuring around $18 \times 26 \mathrm{~cm}$. These are complemented by smaller photographs with an $11 \times 8 \mathrm{~cm}$ format [Pl. 8]. In some cases, a smaller version was added to the larger photograph. Most of the loose photographs also have an $11 \times 8 \mathrm{~cm}$ format. Only 22 of them are $12 \times$ $17 \mathrm{~cm}$. It is also possible to find the same images among the loose photographs as in the albums. A total of 86 such duplications were found. There are 750 unique photographic images on the 836 preserved photographs.

Although we do not have the original negatives, the context shows that the author of most of the photographs is Karel Kř́žek. In one rare case, a label has been preserved in the album, which clarifies the circumstances around the taking of a specific photograph and the brand of camera used. In the photograph of the tomb of Moulay Idris II. in the Moroccan city of Fes, a note is ascribed: 'Photographed while walking with Leica with the aid of a 'look out' around the corner, so that photographing a sacred place did not attract the attention of worshipers' $\left[\mathrm{Pl}\right.$. 9]. ${ }^{20}$ It is likely that most of the $10.5 \times 7 \mathrm{~cm}$ photographs are contact copies of negatives. According to which, the author then chose images to make enlargements from. The author also had six images colored by hand. For 26 images, it is clear that they were purchased by the author of the album. These are six postcards, one panoramic print from Marrakesh, and a set of 26 pieces. of $9 \times 14 \mathrm{~cm}$ souvenir photographs from Milan [Tab. 1].

\begin{tabular}{|c|c|c|c|}
\hline & K. Kř́̌žek & S. Volfová & Total \\
\hline Europe & 104 & 0 & 104 \\
\hline Morocco & 272 & 49 & 321 \\
\hline Algeria & 139 & 45 & 184 \\
\hline Tunisia & 101 & 33 & 134 \\
\hline North Africa (unspecified) & 134 & 20 & 154 \\
\hline Total & $\mathbf{7 5 0}$ & $\mathbf{1 4 7}$ & $\mathbf{8 9 7}$ \\
\hline
\end{tabular}

Tab 1. Photographic images divided geographically 
The images cover the entire journey, from the departure from Prague to crossing the German border, passing through Switzerland and northern Italy to the Mediterranean coast, sailing to Casablanca, traveling through Morocco, Algeria, and Tunisia, and returning home, France, Switzerland, and Germany. The first part of the excursion is documented by 91 photographic images. They capture snapshots from the trip through Germany, a set of 26 purchased photographs of Milan's landmarks, images from Monaco and Marseille, and a series of detailed photographs depicting the loading of the bus onto the ship.

A total of 272 images were taken in Morocco. These are mainly images taken during stops in cities. Most of the images (97) come from Marrakesh. The stops in Fez (34 images) and Casablanca (30 images) are also well documented. At least a few images represent each stop during the excursion around Morocco. The photographer's attention was focused mainly on well-known monuments, but there are also portraits of locals on the streets [Pl. 10] and landscape scenery taken during crossings.

A total of 139 images come from Algeria. Most of them were taken in the Algiers metropolis (39 images), other stops are less represented. Here, too, the photographer's interest focused mainly on the architecture. In addition to mosques and palaces, the local botanical garden in Algiers is also captured. In Chiffa and Cherchell, the main objects of photography were ancient monuments. The images from the stop due to a flat tire [Pl. 11] are interesting.

A total of 101 images come from Tunisia. Most of them (44) were taken in the capital of Tunisia, but Kairouan (19 images) and Medenine (16 images) are also strongly represented. In Kairouan, the photographer's interest focused mainly on the local mosque, and in Medenina on the rock dwellings. From Tunisia there is a series of images of the Bardo Palace [Pl. 12], as well as images recording them leaving port and looking at the city from the deck of the ship on the way back. The end of the journey from Marseille to Prague is documented by 13 images. They mainly capture the historical monuments of Avignon and several images of the Geneva skyline. A total of 134 images could not be geographically placed closer than the North African region. These are mainly undescribed details of architecture or street scenes without defining features.

An interesting addition to Karel Kř́ržek's photographs is a set of 147 postcards and photographs collected by the writer Sida Volfová during the excursion. The Náprstek Museum acquired them in 1962 from the writer's estate from a notary's office in Náchod. They have been registered in the ethnographic photographic collection of the Náprstek Museum. Unlike Karel Křřžek's images, which were his original photographs, these are purchased souvenirs. Most of the set consists of postcards made by printing technology (a total of 129 pieces). One of them even came through the mail. Black and white postcards predominate, but a total of 20 are colored [Pl. 13]. The postcards are complemented by 18 images taken by a photographic technique. Their author is unknown.

The set only contains images of African provenance, images from the European part of the excursion are completely missing here. A total of 49 images come from Morocco, 45 from Algeria, and 33 from Tunisia. A further 20 images cannot be geographically classified. 


\section{Content analysis}

To characterize the thematic focus of photographs, a brief content analysis was performed. ${ }^{21}$ The types of photographic themes developed by the National Library of Norway ${ }^{22}$ were used to determine the categories for coding. These were used to classify the individual photographic images from the whole excursion. Each set was examined separately [Tab 2].

\begin{tabular}{|c|c|c|c|}
\hline & K. Kř́ižek & S. Volfová & Total \\
\hline Architecture & 258 & 36 & 294 \\
\hline Urban landscape & 189 & 49 & 238 \\
\hline Transport & 71 & 2 & 73 \\
\hline Portraits & 65 & 9 & 74 \\
\hline Landscape & 60 & 23 & 83 \\
\hline Nature & 56 & 6 & 62 \\
\hline Reportage & 33 & 0 & 33 \\
\hline Commemorative & 18 & 11 & 29 \\
\hline Documentary & 0 & 8 & 8 \\
\hline Nude & 0 & 2 & 2 \\
\hline Aerial & 0 & 1 & 1 \\
\hline Total & 750 & 147 & 897 \\
\hline
\end{tabular}

Tab 2. Results of content analysis

Amongst the photographs of Karel Křížek, a total of $34 \%$ are photographs of architecture. Together with images of the urban landscape $(25 \%)$, they comprise an overwhelming majority of $59 \%$. The classification of the images into these two categories is not entirely clear. However, the representation of these two categories clearly demonstrates the photographer's interest in architecture, from the oldest ancient monuments, through historic palaces and mosques, to modern architecture [Pl. 14]. and examples of traditional buildings. A total of $10 \%$ of the images can be included in the category of 'transport photographs'. The main theme here is the bus itself, both on the excursion and when being loaded onto the ship [Pl. 15]. In addition, the images show local buses and cars, but also various carriages. There are also various ships in several of the photographs.

An interesting category consists of the 'portraits', which make up $9 \%$ of the images. These are mainly portraits of locals in the streets of cities or the countryside. The portraits are often unarranged, bordering on street photography [Pl. 16]. They capture random passers-by. It is less common to see that the persons photographed pose, as in the case of two dock workers from Sousse, Tunisia [Pl. 17]. The category 'reportage photography', which makes up $4 \%$ of the images, is directly related to the portraits. These capture various daily activities - the performance of a snake charmer [Pl. 18], washing clothes, or carrying water. One series of images is dedicated to the French Foreign Legion, both at a concert in Fez, Morocco, and the embarkation of soldiers onto a ship in Tunis. 
Natural themes predominate in $16 \%$ of the images: a total of $8 \%$ can be included in the category 'landscape photography'. These are mainly various scenery of the desert landscape or rock formations in the mountains, taken during crossings between individual cities. The landscape images of North Africa are complemented by several images of the European Alps. Also, $8 \%$ of the images were included in the category 'nature photography', which capture plants and a whole range of animals: storks, swans, monkeys, donkeys, horses, and camels [Pl. 19].

The category 'commemorative photographs' includes images that capture the participants of the excursion. These are either arranged images or snapshots documenting the course of the excursion: loading luggage, visiting a café, or riding a camel. Unfortunately, not all of them are described, so it was not possible to identify all of the participants. There are surprisingly not many, accounting for only $2 \%$ of all the images. This indicates that the photographer was primarily interested in capturing the surroundings and not in proving his own presence in specific places. However, Mr. Křížek, the author of the photographs, can still be found in a few of the images [Pl. 20].

A set of postcards and photographs from Sida Volfová shows similar characteristics, despite its difference in size and type of photographic material. Photographs of urban landscapes (33\%) and architecture (25\%) predominate. Together, they form an absolute majority, similar to the photographs of Karel Křižek. The captured themes are also similar: city complexes and details of buildings, especially historical monuments.

A total of $16 \%$ of the images are represented by landscape photography, mainly deserts and mountain scenery. Nature photography is represented by $4 \%$ of the images and includes palm trees and camels. Most of the photographs in the set can be included in the souvenir photograph group, because they capture participants riding camels (including Sida Volfová herself) [Pl. 21] or in the form of arranged portraits. Portrait photography alone is represented by $6 \%$ of the postcards, which show portraits of locals. Most of them are taken in a natural environment, with three being studio photographs. Documentary photographs (5\%) capture common everyday activities: the work of goldsmiths, the performance of a snake charmer, or a chess or domino player [Pl. 22]. In the order of units, the set also includes photographs of transport (2 pieces), nude photographs (2 pieces), and one aerial photograph [Pl. 23].

\section{Conclusion}

The surviving photographic documentation from the teachers' excursion to North Africa in 1936 represents a comprehensive source of information which is exceptional in the context of the photographic collections of the Náprstek Museum. It is valuable both as an example of tourist photography of the 1930s and for its rich documentation, thanks to which it is possible to reconstruct the whole excursion day-by-day and assign the preserved photographs to specific dates and events.

Unlike famous travelers of that time who presented their photographs publicly in books and lectures, tourist photographs served originally as a memory for the tour participant and close family and friends only. The photographs of Karel Kř́žzek, together with Jarmila Vajglová's notes and articles and postcards of Sida Volfová, represent a comprehensive source of information and may be used as the basis for further research and publication. 
Both sets were examined in terms of authorship, technical parameters, and geographical location. While Karel Křižek took most of his photographs himself, another set collected by Sida Volfová features postcards and photographs by other authors. The most represented country in both sets is Morocco, followed by Algeria and Tunisia. In addition, photographs of Karel Kř́žžek also cover the journey from Prague to Marseille and the return journey.

A simple content analysis was carried out to determine the most represented topics. Architecture and urban landscapes make up an overwhelming majority in both sets, followed by landscapes. Karel Křížek also focused on nature, transport, and portraits. Commemorative photographs in both sets are not as numerous. They document the course of the excursion and participants themselves.

Photographs presented together with several memories of certain periods of the excursion have become a comprehensive source of lasting value, which may be used for research into the history of travel, tourist photography, and the history of relations between the former Czechoslovakia and the countries of North Africa. It is prospective that during research in archives, other materials related to this excursion may also be found.

The whole collection of photographs from the excursion is available at: https://esbirky.cz/hledat/fond/40010779.

\section{Literature:}

Beran, J. (2013). Historie Exodu aneb Jak to začalo... [History of EXOD or How it Begun, online] 60 let EXOD. Českomoravský odborový svaz pracovníků ve školství. Available at: https://skolskeodbory.cz/sites/skolskeodbory.cz/files/galleries/soubory/1501766913/ almanach_exod.pdf [Accessed 16 May 2021]

Baudisch, P. (2013). Norský národní standard pro evidenci fotografií v pamětových institucích [Norway's National Standard for Record Keeping of Photographs in Memory Institutions]. Historická fotografie, 12, pp. 50-67.

Bulínová, M. and Hořčičková, E. (1971). Exod (Exkurní odbor Ústř. spolku učitelských jednot na Moravě) [Exod (The Excursion Department of the Central Association of Teachers' Unions in Moravia)]. Učitelské noviny, 21(7), p. 10.

de Avelar Pinheiro, N. (2008). Tourist Photography. Encyclopedia of nineteenth-Century Photography, New York, pp. 1397-1400.

Gruhier, B. (2019). Les véhicules de la collection AAF - Le Citroën C6 [The Vehicles of the Historic Cars of France Collection - Citroën C6, online] Bulletin d'information. Autocars Anciens de France $N^{\circ} 47$, pp. 2-3. Available at: https://autocarsanciensdefrance.fr/ docs/lettres-info/bi-n-47-octobre-2019.pdf [Accessed 20 May 2021].

Kam pojedete letos? Jed'te s námi! [Where are you going this year? Come with us!] (1936). Střední škola, pedagogická část Věstníku českých profesorů, 16(5), pp. XIVk-XIVn. 
Program cest Exkursního odboru Ústředního spolku jednot učitelských v zemi Moravskoslezské [Travel Programme of the The Excursion Department of the Central Association of Teachers' Unions in Moravia/Silesia]. (1934). Střední škola, pedagogická část Věstníku českých profesorů, 15(2), pp. I-IV.

Program cest a zájezdi̊ v létě 1938 [A Programme of Trips and Tours in the Summer of 1938] (1938). Středni škola, pedagogická část Věstníku českých profesorů, 3(5), pp. 1-4.

Rose, G. (2012). Visual Methodologies. London.

Sádlo, V. (2012). Náchod za Protektorátu [Náchod during the Protectorate]. Náchod.

Smith, G. (2013). Photography and travel. London.

Volfová, S. (1936a). Afrika láká [Africa allures]. Večerník Národních listů 76(238), p. 4.

Volfová, S. (1936b). Afrika žhne... [Africa glows...]. Večerník Národních listi̊ 76(241), p. 4.

Volfová, S. (1936c) Afrika voní... [Africa smells nice...]. Večerník Národních listio 76(245246), p. 4.

Volfová, S. (1936d). Asni-Rabat. Večerník Národních listů 76 (261-262), p. 4.

Volfová, S. (1936e). Cestou k Fezu [On the way to Fez]. Večerník Národních listů $76(266)$, p. 4.

Volfová, S. (1936f). Africká Šípková Růženka [African Sleeping Beauty]. Večerník Národních listů 76(272), p. 4.

Volfová, S. (1936g) Napříč severoafrickou pustinou. [Across the North African wasteland]. Večerník Národních listů 76(280-281), p. 4.

Volfová, S. (1936h). Pekelná jízda pozemským rájem. [Hellride through the paradise on earth]. Večerník Národních listů 76(287-288), p. 4.

Volfová, S. (1936i). Bouře nad oasou [Storm over the oasis]. Večerník Národních listů 76(300), p. 4.

Volfová, S. (1936j). Za branou Sahary [Beyond the gate of the Sahara]. Večerník Národních listů 76(304-305), p. 4.

Volfová, S. (1936k). Mekka východu [Mecca of the East]. Večerník Národních listů 76(309-310), p. 4.

Volfová, S. (19361). Kraj troglodytů [Land of Troglodytes]. Večerník Národních listů 76(316-317), p. 4. 
Volfová, S. (1936m). Afriko, na shledanou [Africa, goodbye]. Večernik Národních listi̊ 76(323-324), p. 4.

\section{Archival sources:}

National Museum - Náprstek Museum of Asian, African and American Cultures, register of originators, Kř́žzek Karel folder.

National Museum - Náprstek Museum of Asian, African and American Cultures, ethnographic photographic collection, Inv. nos. Af III 436 - Af III 806; Af III 875 - Af III 1020; Ev III 38 - Ev III 131.

Moravian Regional Archive, collection of the Central Association of Teachers' Unions in the Moravian - Silesian Land. 
A F $R$ \& A 1936.

30.VI. Praha, odj. v 5.30; Plzeñ, Inichov, Garmiscg Partenkirchen.

1.VII.Garmisch Partenkirchen - Lardopk - velehorskjm Bngadinem na St.

2. Mlán - Janov - po italské kivter̆e na S. Rêmo, Kenton, Nonte Carlo.

3. Jonte Carlo - francouzská Rivibra : Niza - Jannes - St. Raphael -

4. Harseilie - odj. Lodi $\mathrm{v}$ li hod.

5. Na mกห̆.

6. Ya mor̂t - zastávka v Tangeru, rohlidka mèsta.

7. Vylodèni v Casablance. Dopoled prohlidka.mèsta, odp. odj. do

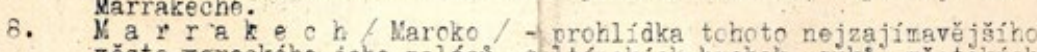
mĕsta marockého, jeho palácú, sultánských hrobek, -sukú, rěstských hradeh, palmového lesa; $k$ večríl produkce domorodcú na námèstí Djema el Fna.

10. Jarrakech : vỷlet do Asni ve Vyokém Atlasu. hradu $\nabla$ Varoki / - Buujad - Cupd Zer - Cäsablance \% vocerní život

$\checkmark$ domorodé ètvrti/.

1. Casablanca - $R$ a b a t / residence marockého sultána / Přij. v . 10 hod.; prohl.: Kasha Oudaía, arakské mĕsto; odpoledne : Cholla 3 hmbkamí sultănú, věž Hassan va $\mathrm{s}$ nádhernýr pohledes nà mĕsto;

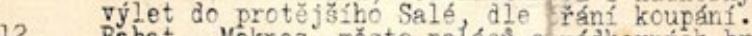

12. Rabat - Néeknes, mésto palácú a nádherných bran; zříceniny řimské-

13. ho mĕsta Volubilis ; svaté měs : mohamedánu Koulay Id̂riss; Fez.

13. Fez- sidlo marockého umĕní

14. $\mathrm{Yez}$ - Taza - Cudjda.

15. Cudjô - Tlemcen / prohlidka mizit / - Oran.

16. Oran - Kostaganem / koupání / enes. na na cherchel / rimské trosky/, Tenes - po nadhemém morském p proži na Cherchel rimské trosky. Alžír. 18. A 1 í 1 - prohlidka města, fliherné botanické zahrady, koupání. herberské tanečnice

20. Bou Saada - pouští na oasu Tolfi, Biskra / proslulá oasa na nkraji. Sahary, klimatické láznĕ.

21. Fiskra - El Kantara/ "Rrána ouštĕ "/, Eatna, římské zřiceniny

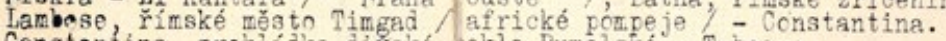

22. Conctantina, prohildka diroké okla Rumelské - Tobessa.

23. Tobosa - Tozeur - oasa 200.00 palem na brehu nejuětšiho jezera

24. Tarickéhn - Sot el Džeridu.

Pl zorid - ahes / krásná oasa, pr̆istav.

Gabes - Kẻdenine / hlavni mëst jižniho Tinisska; bunkorité 'pr̆i-

bytky "Ghorfy " v blocich nad sèbou; Matmata, semé trogloditu,

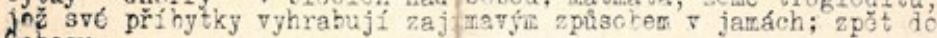

26. Gabes - Siax / prchlidke, koupeni / Bl Djem/ rimský amfiteátr/,

27. Sousse - svaté město Kairuan / prohlídka proslulých mešit, přis-

28. tupným nevěrícim turistür / - Tunis.

1 ú n 1 s : prohlidka mĕsta, peláce beyova a Barde ; odpoledne

29. Puris, $x^{3}$. lodi 711 hod.

31. Uarsaills, pŕ1j. V 14 hod; ; od do Aviknonu ; prohlidka, nocleh.

I.VIII, Zereva - jedrou z nejpéknéjş ch cest pres Svýdeary - po brezich Zenevského jezera na Lausanne, Vevey, Chatel St.Denis - Bulle -

Chatoau d Oex - pres Jaunský prusmyk' $k$ Tunskému jezeru, na Interlaken, po brezích jezera Briensskéhs, Sarnenského, Vierwaldstät-

takého do Luzerru,

2. Luzern - Zïrich - Winterthur - St. Gallem - Rregenz - Lindava -

3. Kemptar - Mnichov

Pxogramez tímto opraxlaje se program předběžný, vydaný

letos v únoru. Upob̌tí so od návštèvy Touggourtu, od níz nás zrazují

mistni ciritelé. Misto Touggortu uvioime Rou Saadu, typickou oasu na 


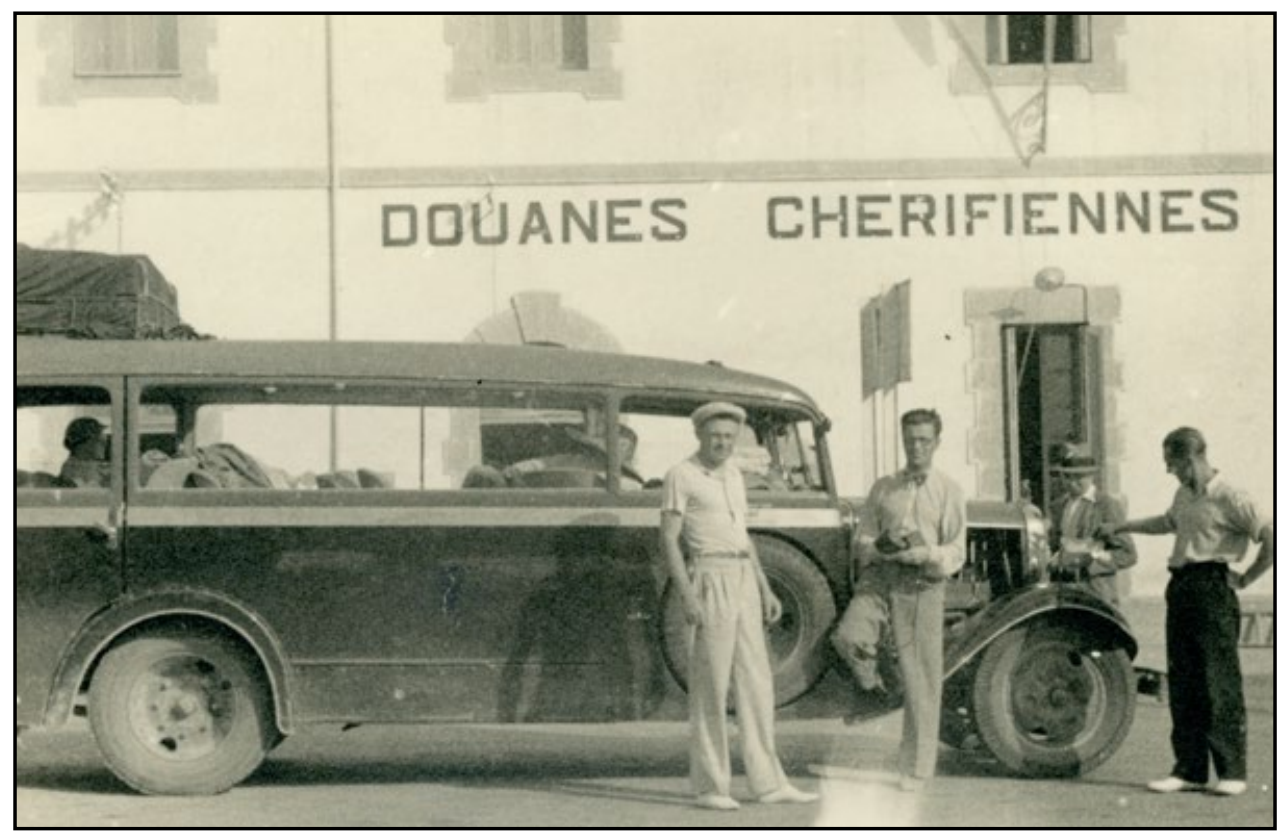

Pl. 2. Expedition bus on the border of Morocco and Algeria. On the left, the owner of the bus, Mr. Šterba, the leader of the expedition, Mr. Peč, on the far right, the second driver, Kozák. 15 July 1936. Photograph by K. Křížek, National Museum - Náprstek Museum, ethnographic photographic collection, Af III 1991.

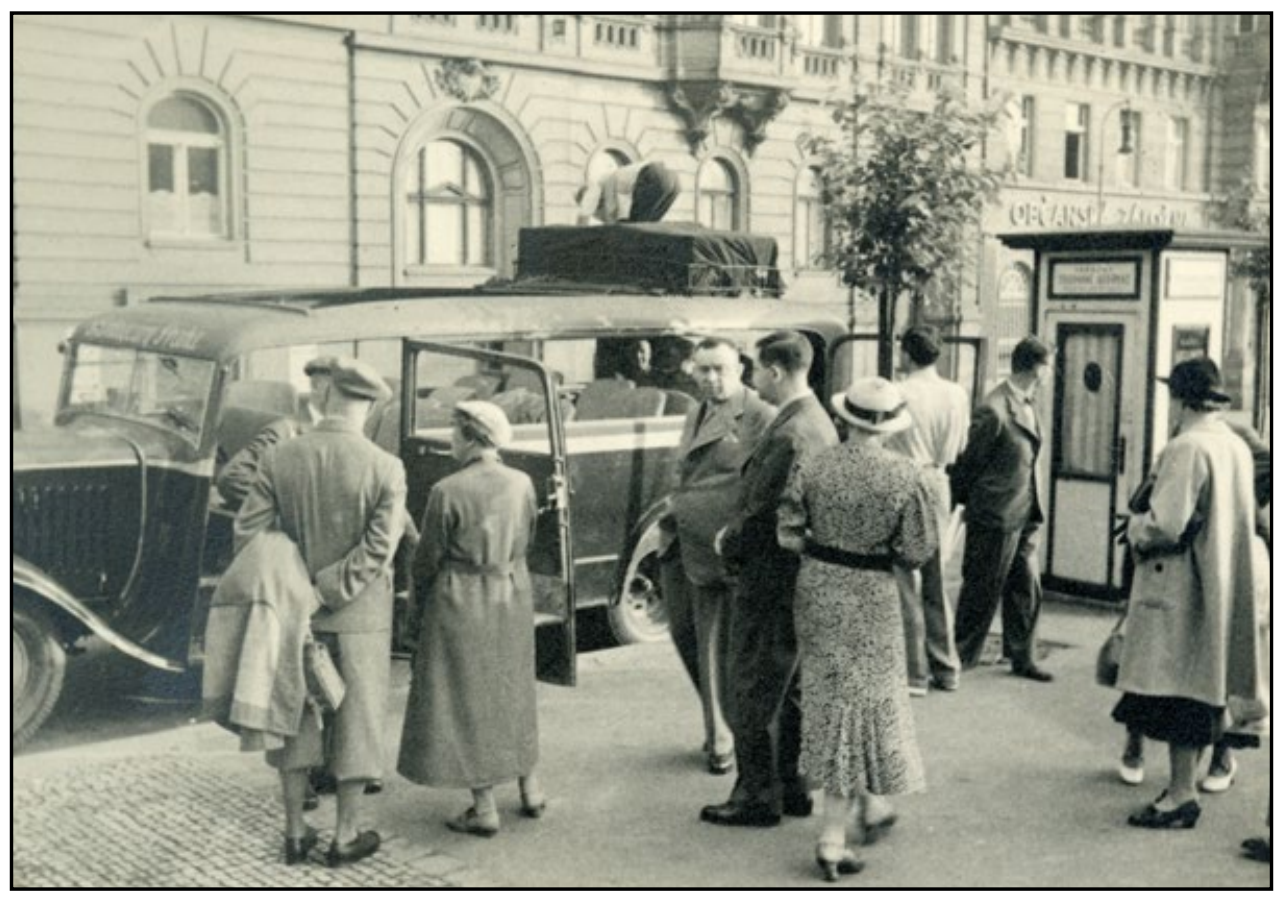

Pl. 3. Bus before leaving Prague in the morning of 30 June 1936. Photograph by K. Křížek. National Museum - Náprstek Museum, ethnographic photographic collection, Ev III 42. 


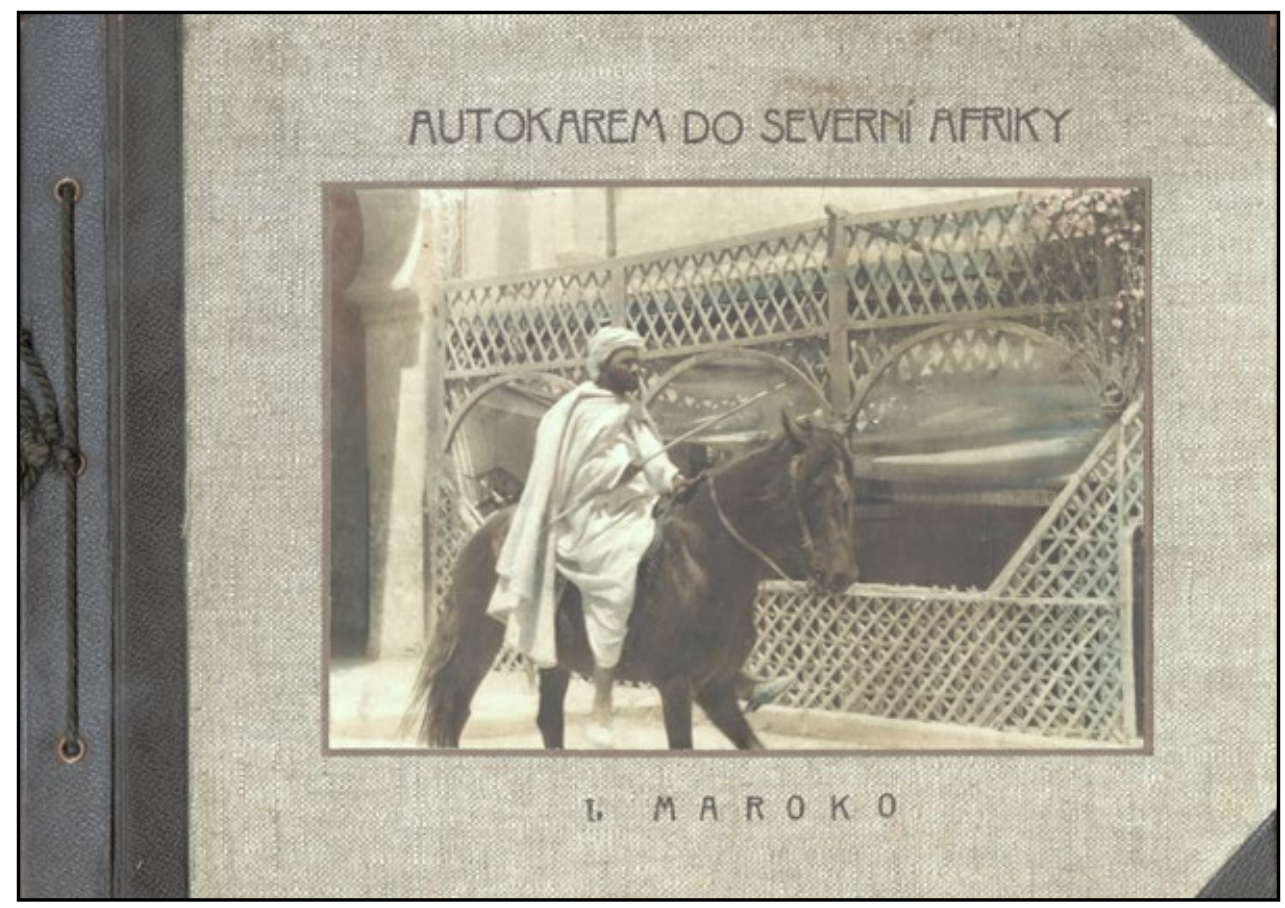

Pl. 4. Records of the first album with photographs from Morocco with a colored photograph of a Moroccan rider from Fez pasted into it.

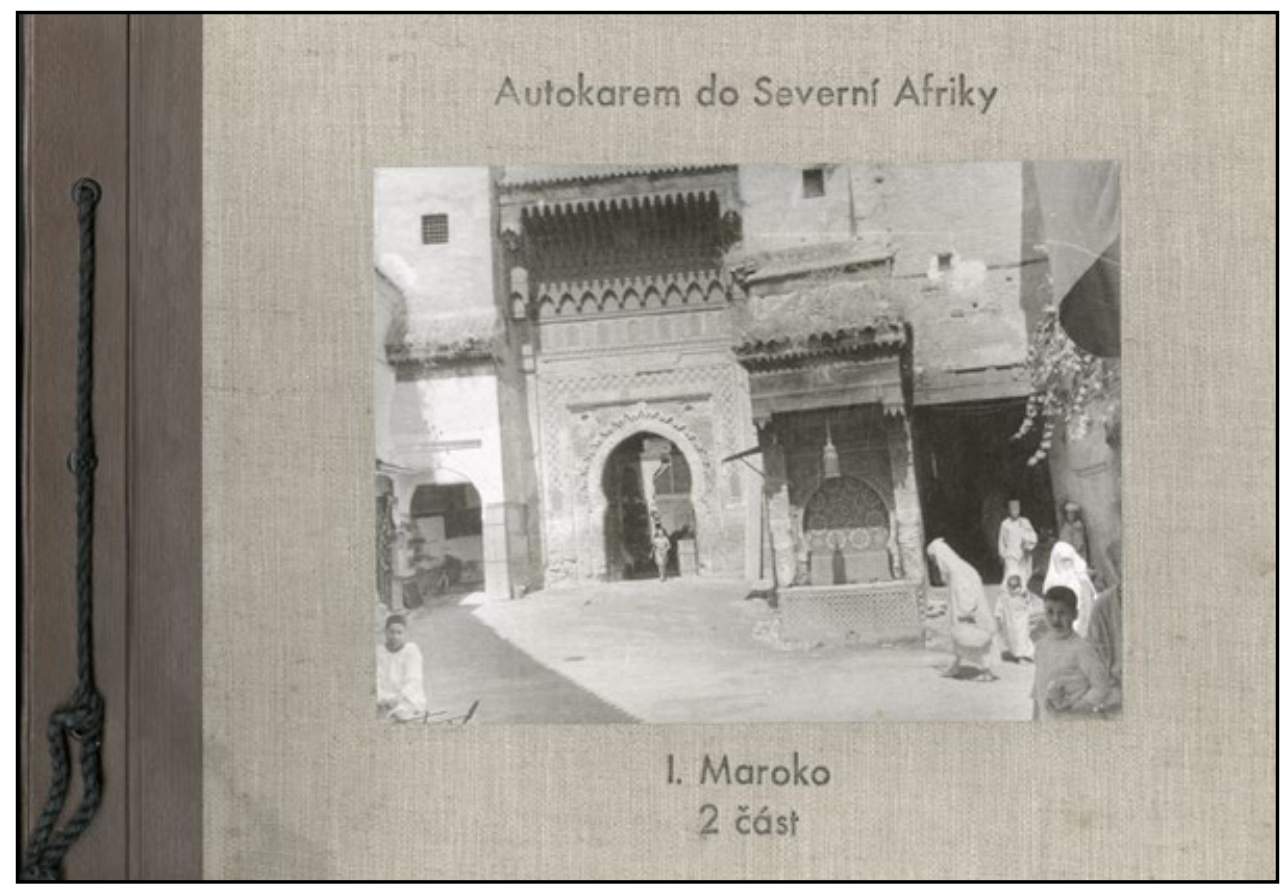

Pl. 5. Records of the second album with photographs from Morocco with a pasted photograph of the Nejarine fountain in Fez. 

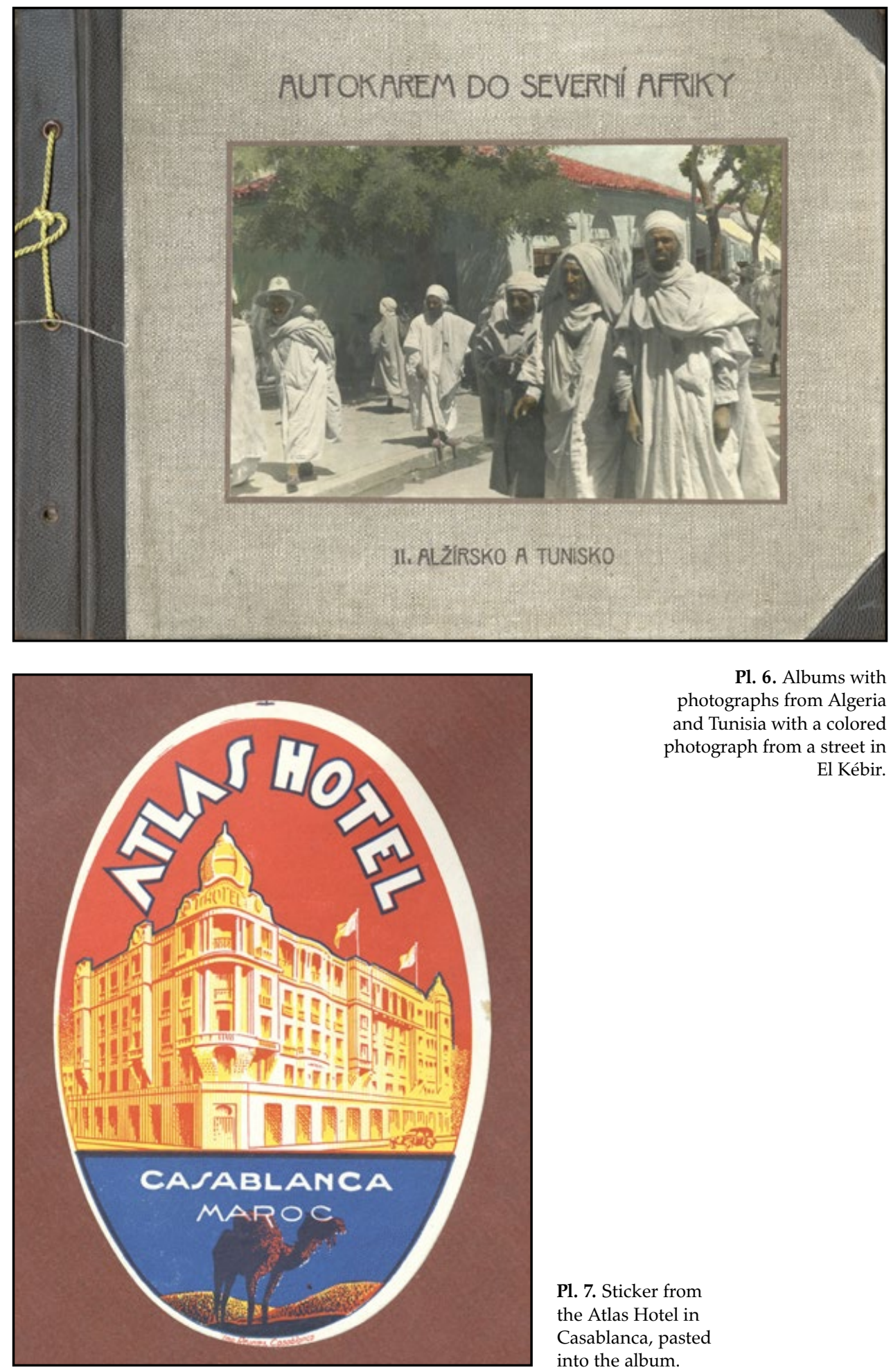

P1. 6. Albums with photographs from Algeria and Tunisia with a colored photograph from a street in El Kébir.

Pl. 7. Sticker from the Atlas Hotel in Casablanca, pasted into the album. 

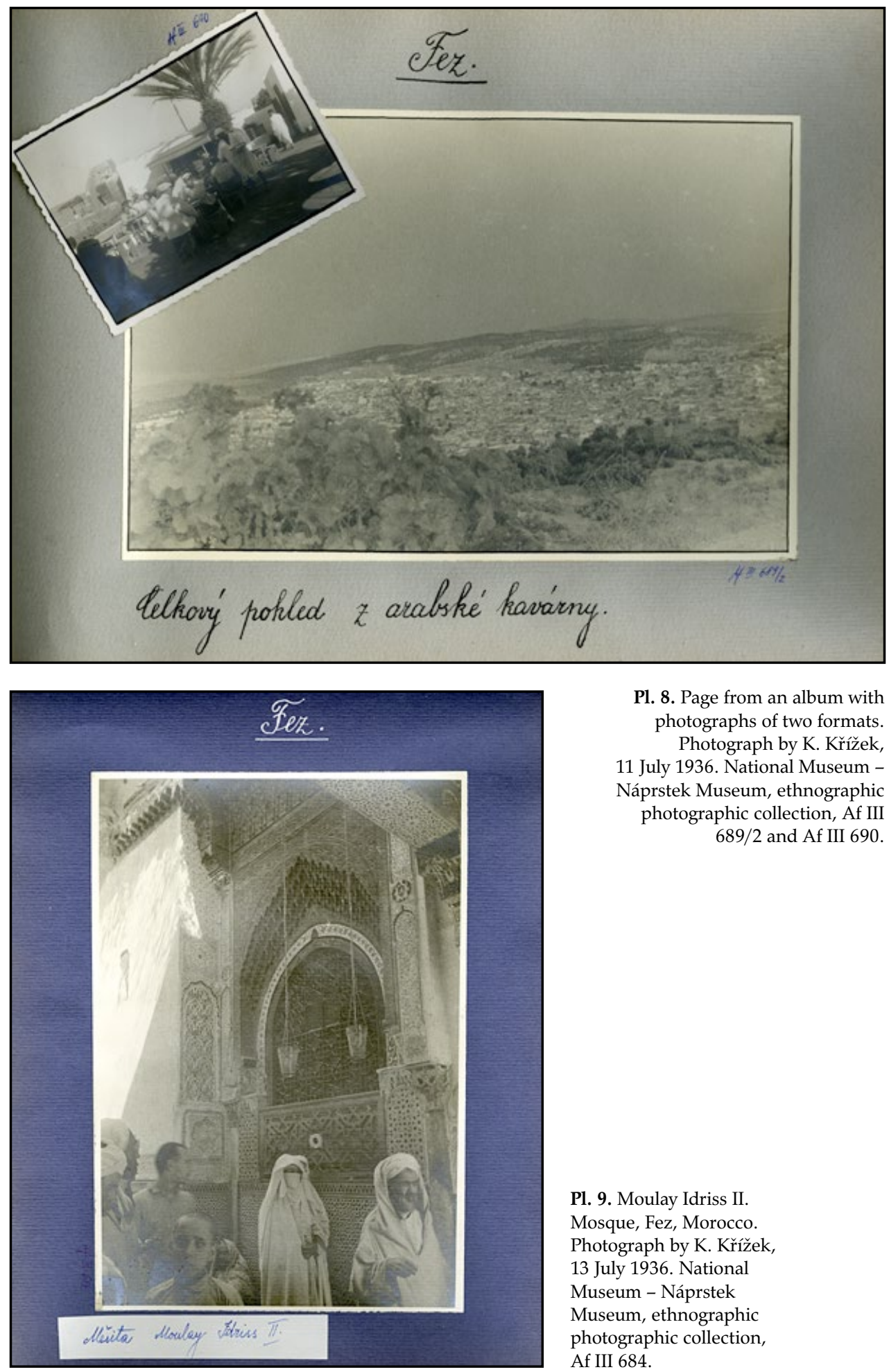

P1. 8. Page from an album with photographs of two formats. Photograph by K. Kř́ížek, 11 July 1936. National Museum Náprstek Museum, ethnographic photographic collection, Af III 689/2 and Af III 690.

P1. 9. Moulay Idriss II. Mosque, Fez, Morocco. Photograph by K. Křižžek, 13 July 1936. National Museum - Náprstek Museum, ethnographic photographic collection, Af III 684. 

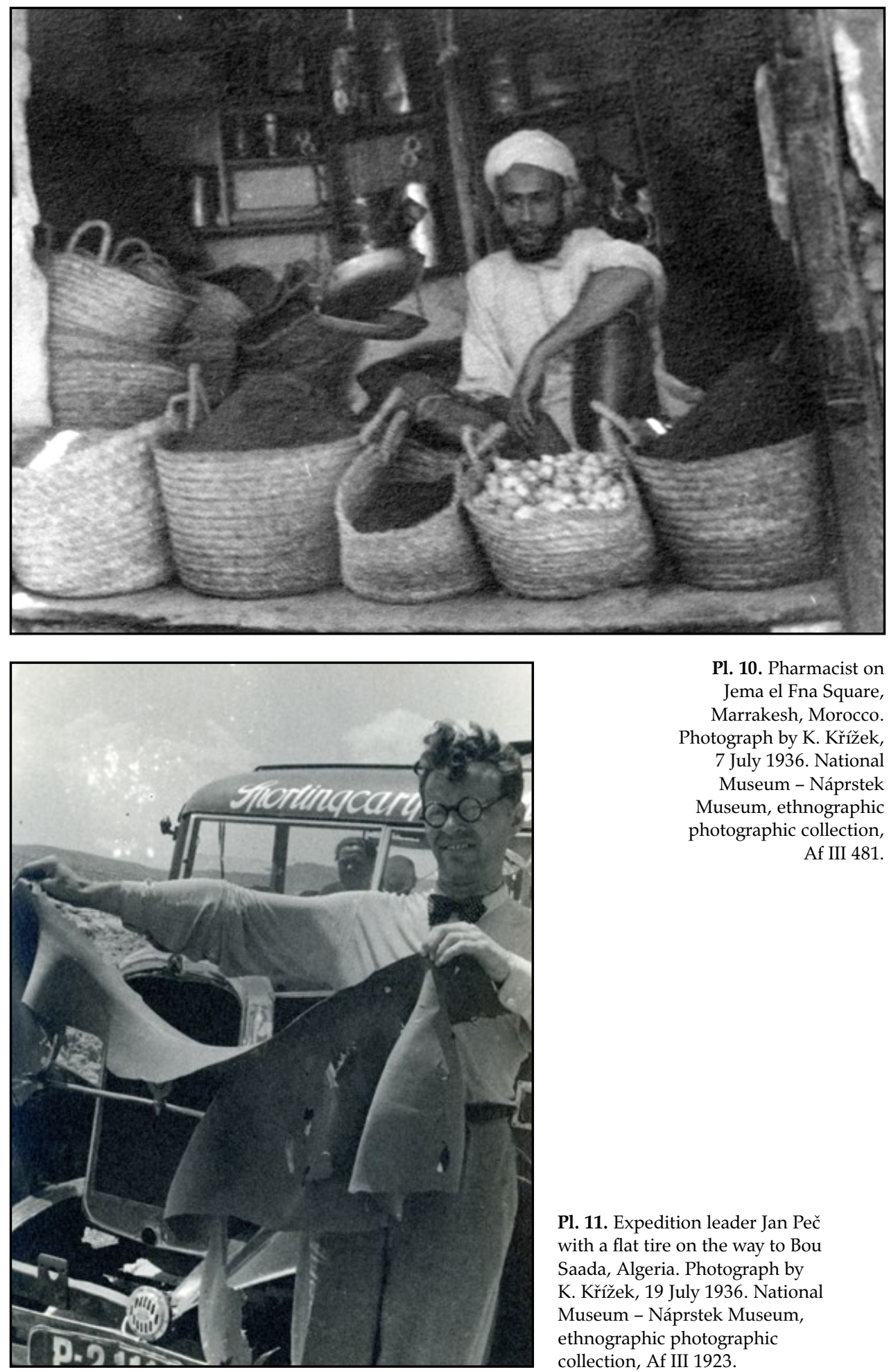

Pl. 10. Pharmacist on Jema el Fna Square, Marrakesh, Morocco Photograph by K. Křížek, 7 July 1936. National Museum - Náprstek Museum, ethnographic photographic collection, Af III 481.

P1. 11. Expedition leader Jan Peč with a flat tire on the way to Bou Saada, Algeria. Photograph by K. Křížek, 19 July 1936. National Museum - Náprstek Museum, ethnographic photographic collection, Af III 1923. 


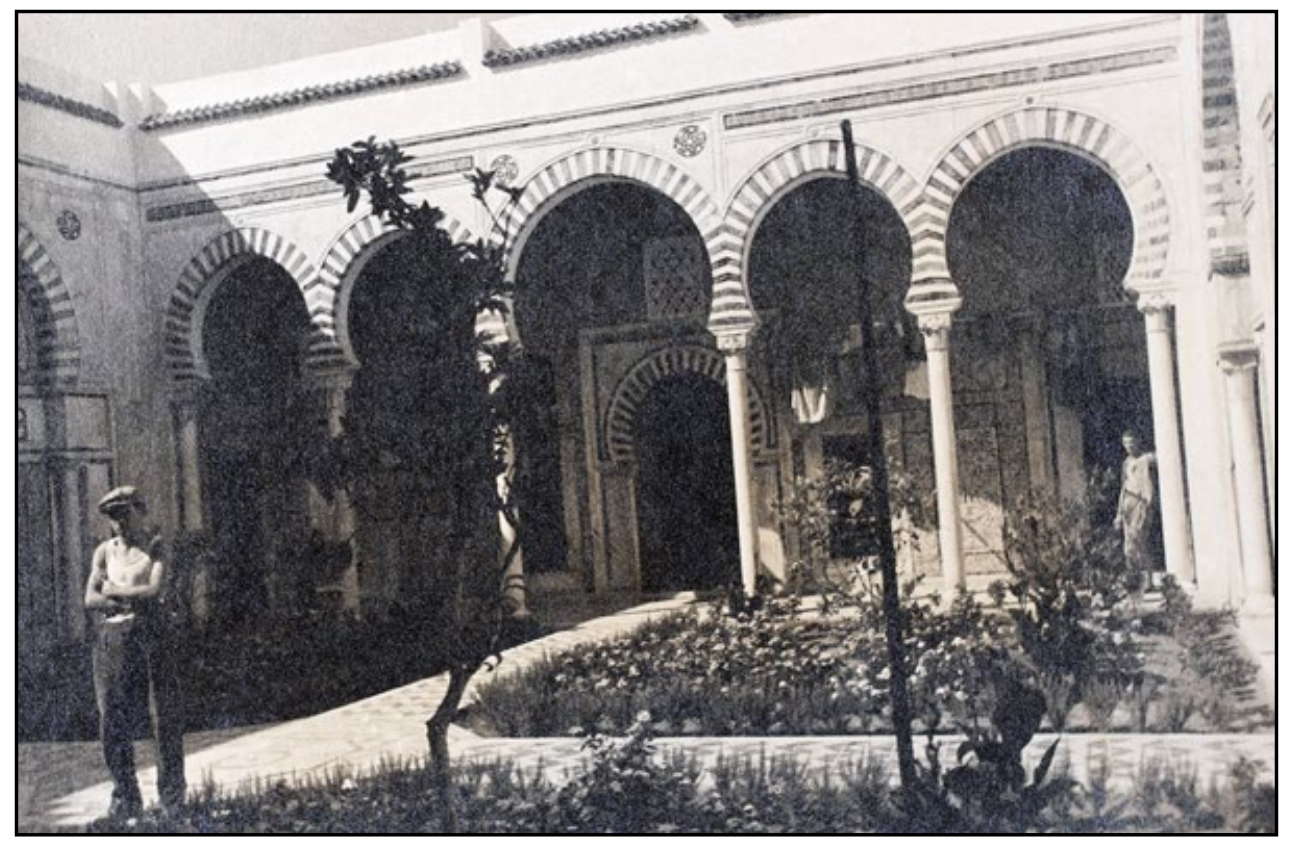

Pl. 12. Courtyard of Bardo Palace, Tunis, Tunisia. Photograph by K. Křížek, 24 July 1936. National Museum - Náprstek Museum, ethnographic photographic collection, Af III 800.

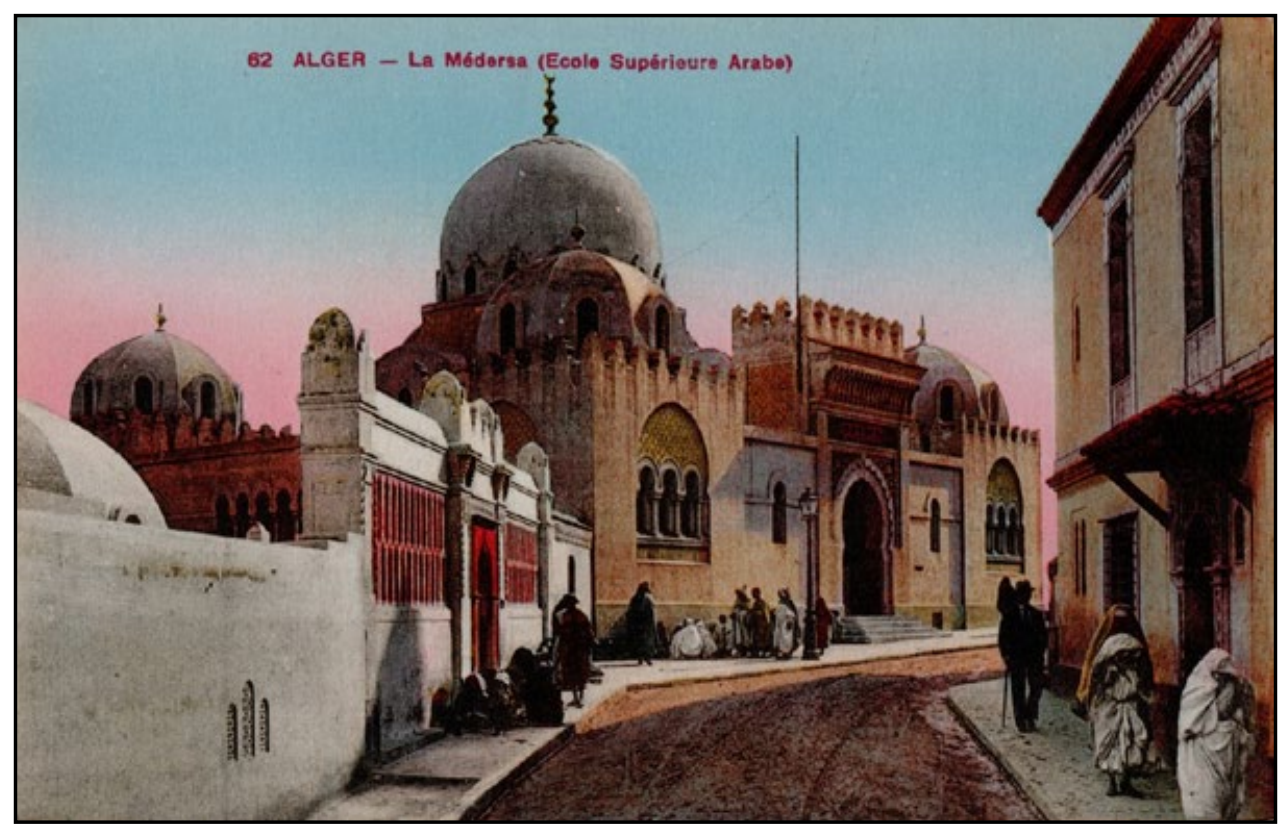

Pl. 13. Entrance to the Madrasa, Algiers, Algeria. Colored postcard from the estate of Sid Volfová. National Museum - Náprstek Museum, ethnographic photographic collection, Af III 833. 

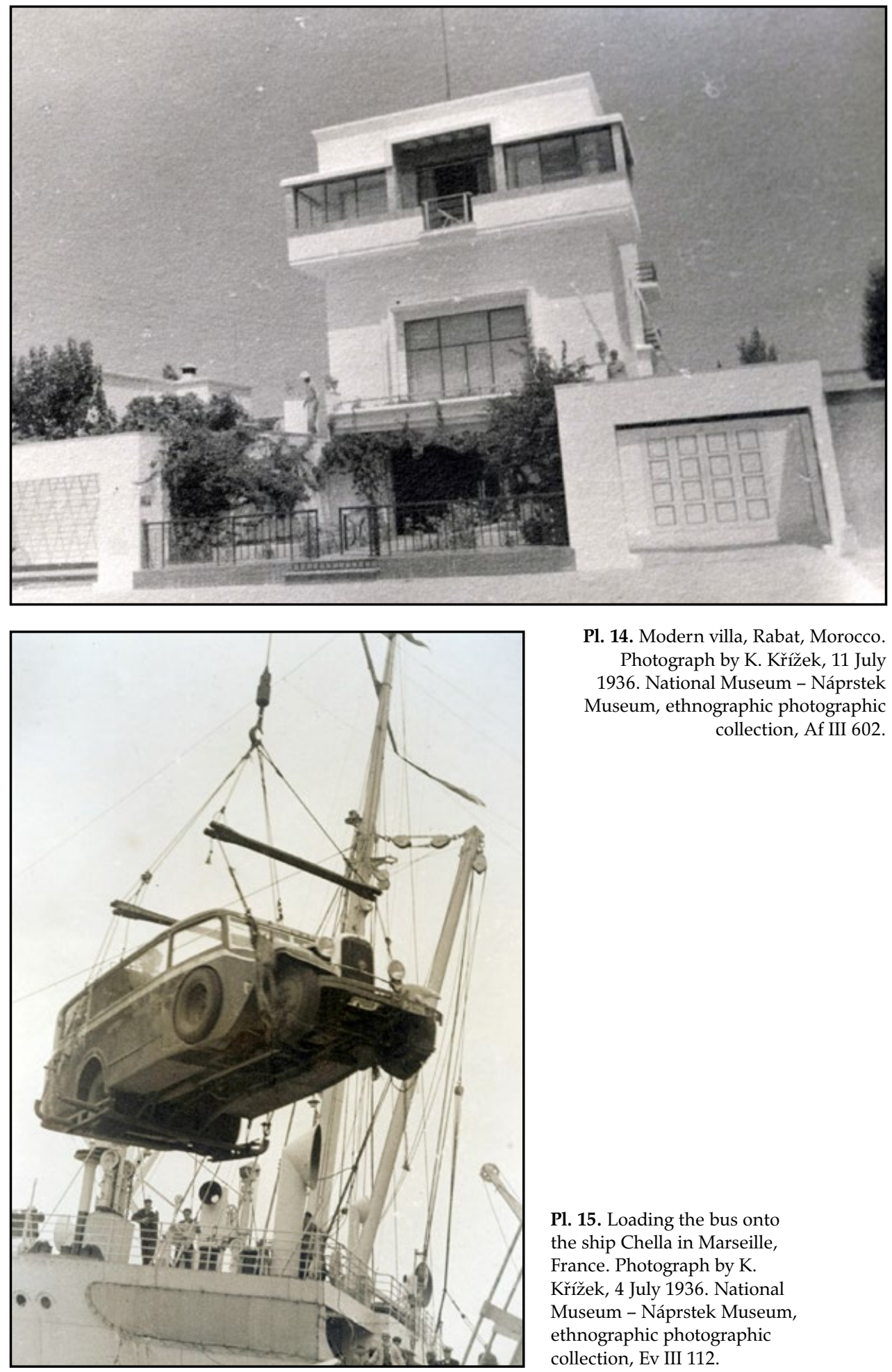

Pl. 14. Modern villa, Rabat, Morocco. Photograph by K. Křížek, 11 July 1936. National Museum - Náprstek Museum, ethnographic photographic collection, Af III 602.

Pl. 15. Loading the bus onto the ship Chella in Marseille, France. Photograph by K. Kř́žzek, 4 July 1936. National Museum - Náprstek Museum, ethnographic photographic collection, Ev III 112. 


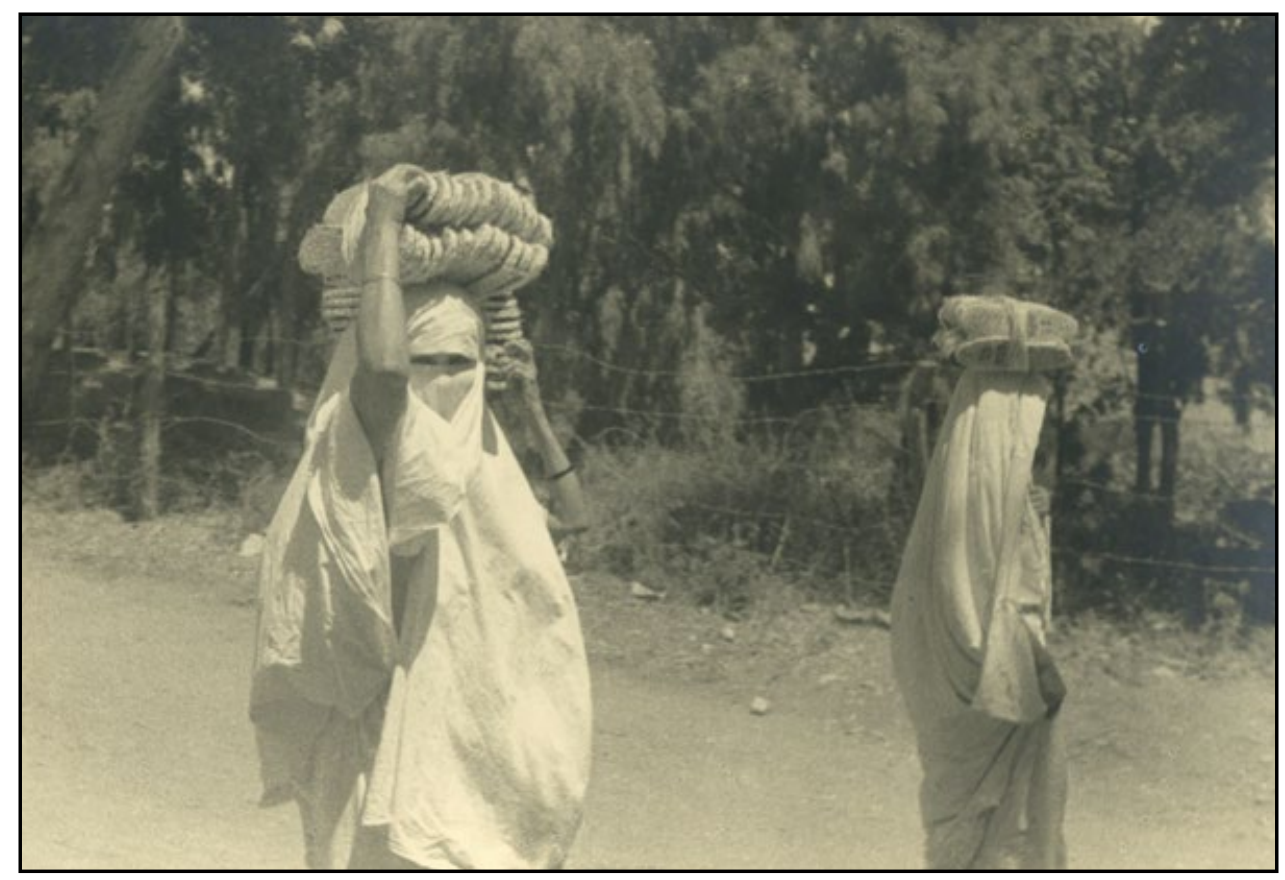

Pl. 16. Veiled women selling shoes. Algiers, Algeria. Photograph by K. Kř́žzek, 18 July 1936. National Museum - Náprstek Museum, ethnographic photographic collection, Af III 733.

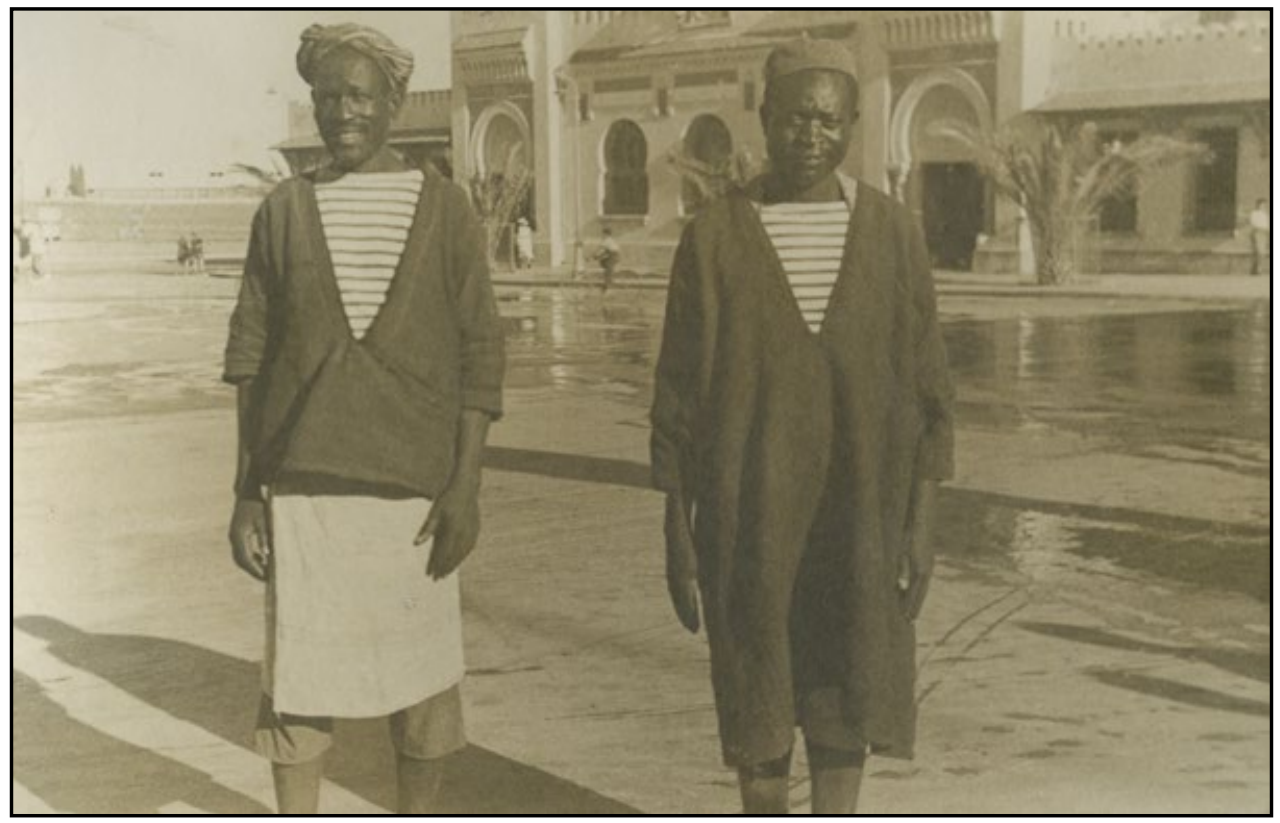

Pl. 17. Two dock workers, Sousse, Tunisia. Photograph by K. Kř́žžek, 25 July 1936. National Museum - Náprstek Museum, ethnographic photographic collection, Af III 786. 


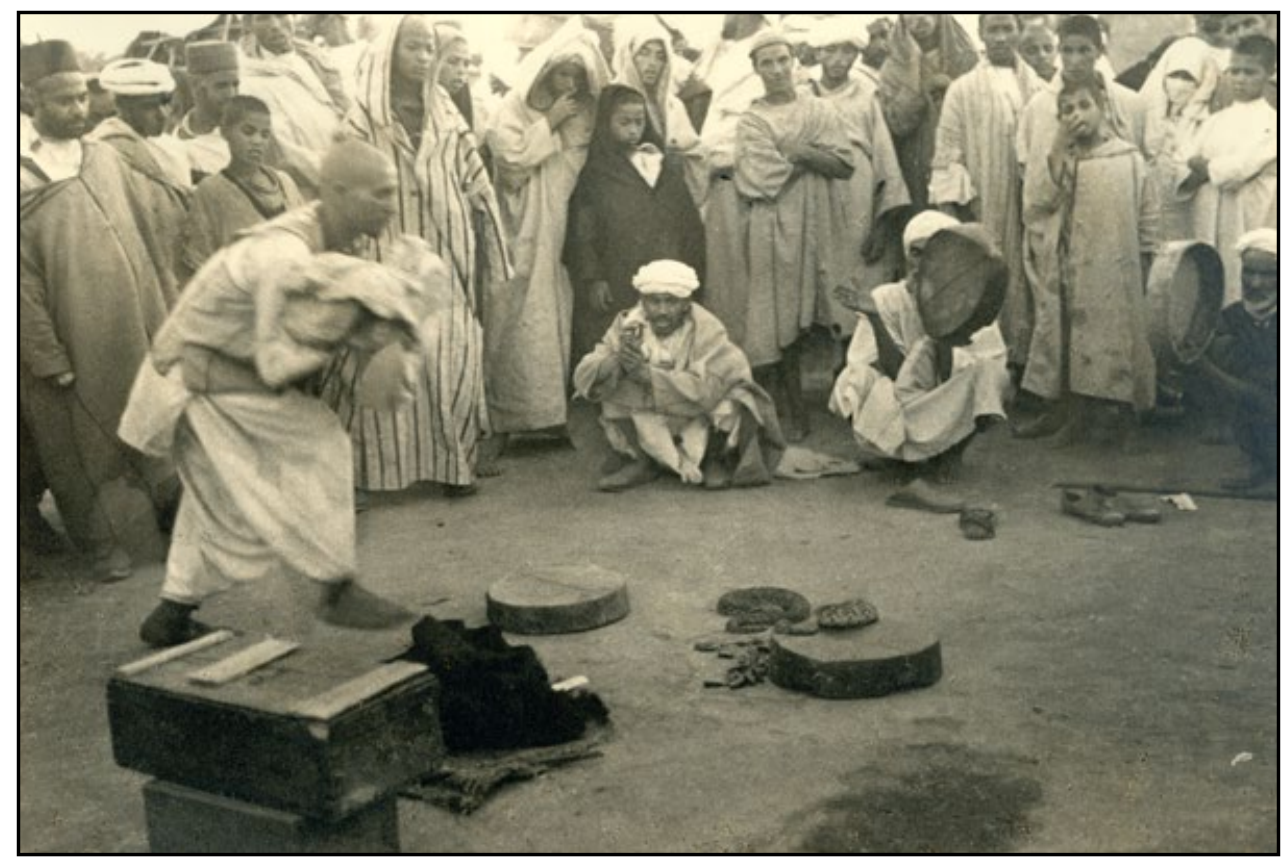

Pl. 18. Performance of a snake charmer. Marrakech, Morocco. Photograph by K. Křížek, 8 July 1936. National Museum - Náprstek Museum, ethnographic photographic collection, Af III 555.

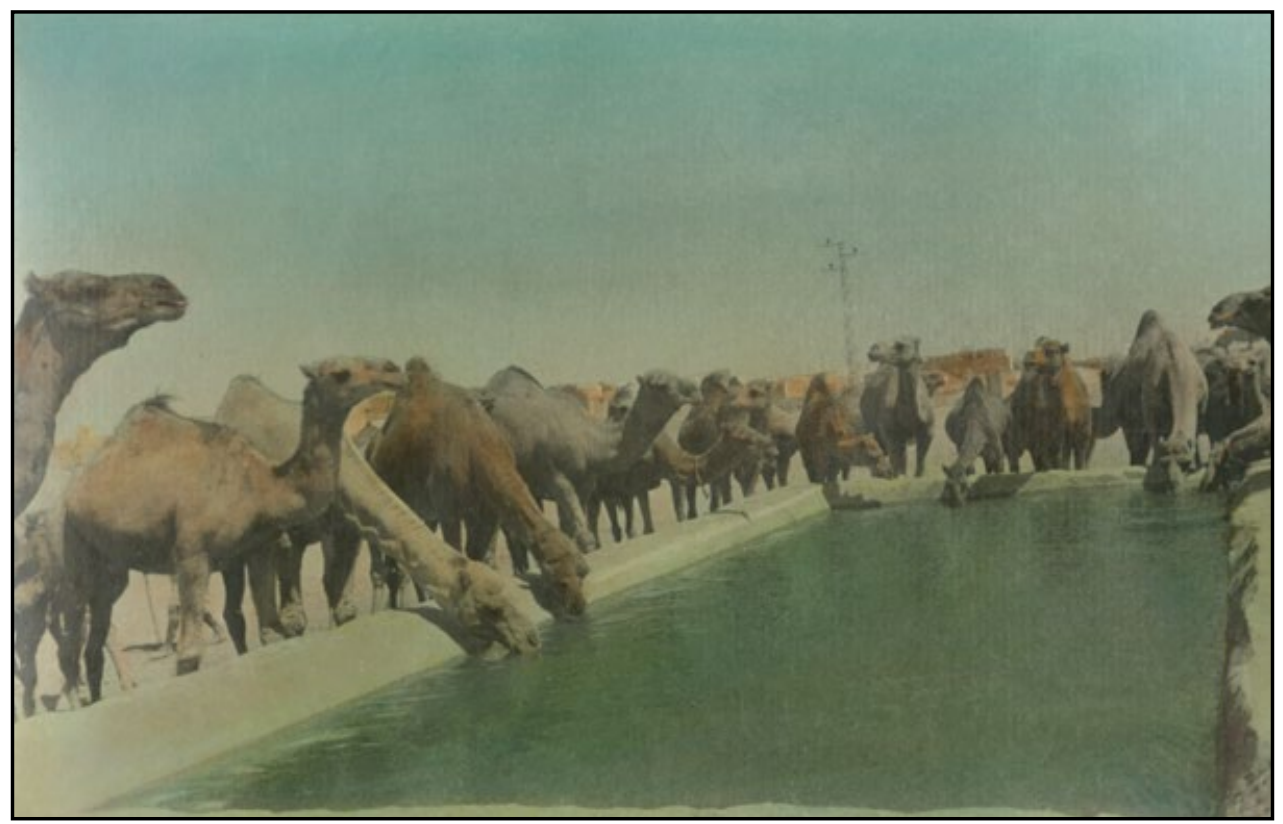

Pl. 19. Camels at the watering hole. Color photograph. Kairouan, Tunisia.

Photograph by K. Kř́ržek, 24 July 1936. National Museum - Náprstek Museum, ethnographic photographic collection, Af III 780. 


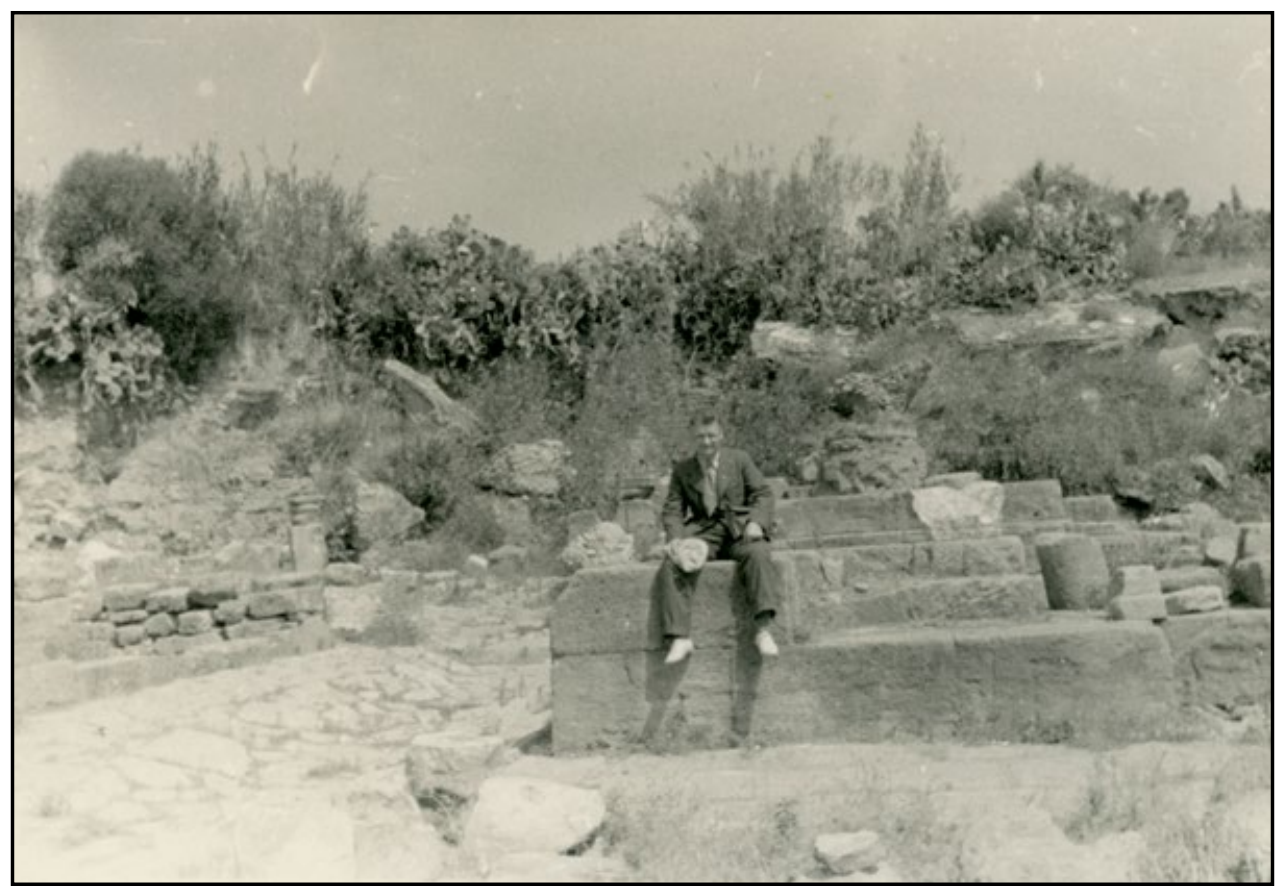

P1. 20. Author of the photographs Karel Křížek near ancient monuments. Chella, Morocco. Author undetermined, 11 July 1936 National Museum - Náprstek Museum, ethnographic photographic collection, Af III 1934.

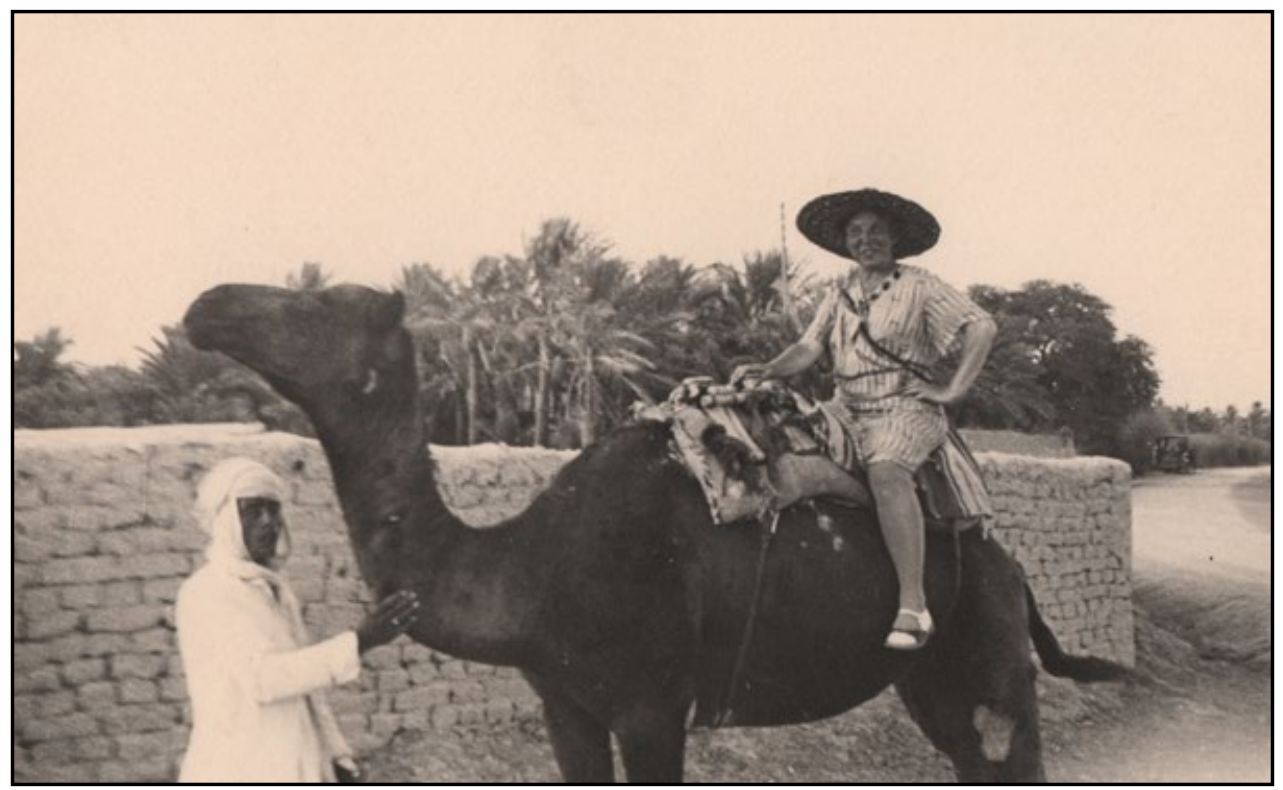

Pl. 21. Sida Volfová riding a camel. Biskra, Algeria. Author undetermined, 19 July 1936. National Museum - Náprstek Museum, ethnographic photographic collection, Af III 897. 


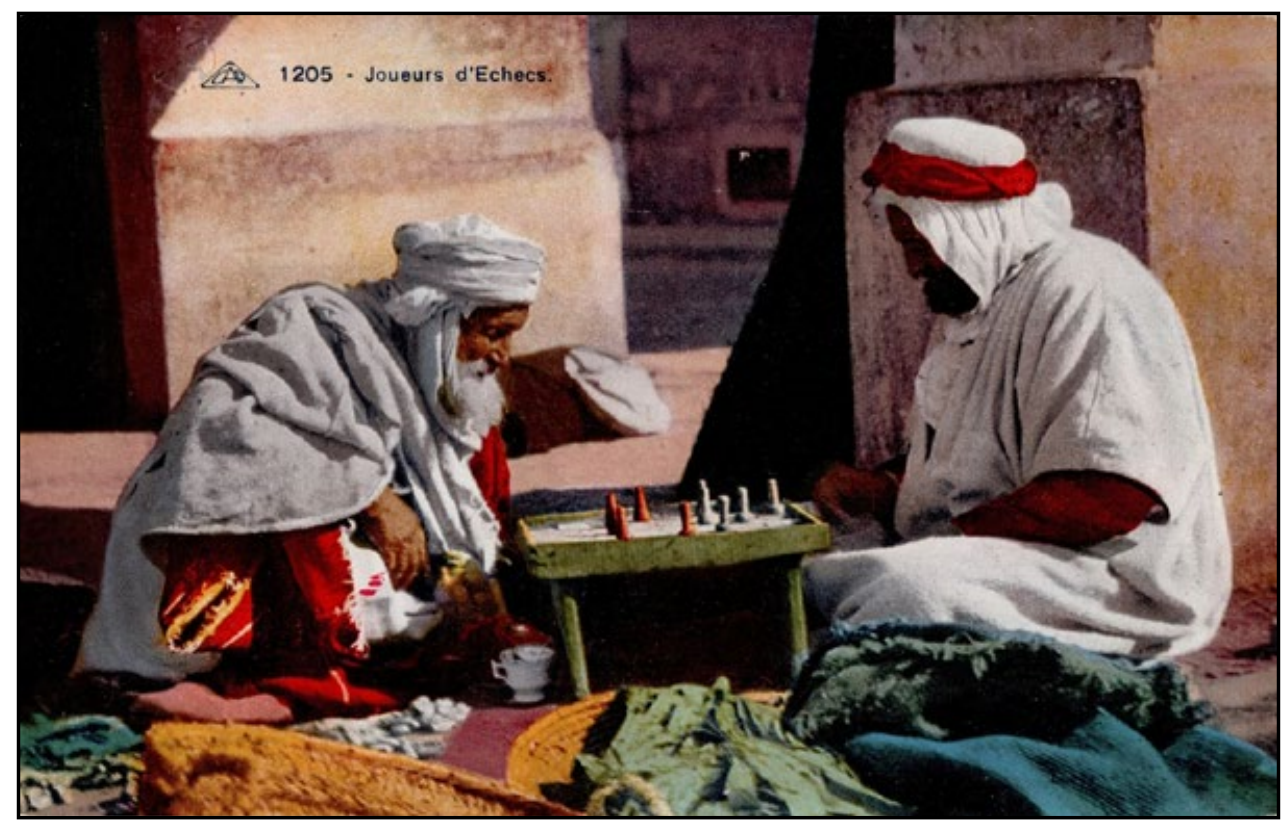

Pl. 22. Chess players. North Africa. Colored postcard from the estate of Sida Volfová. National Museum - Náprstek Museum, ethnographic photographic collection, Af III 1001.

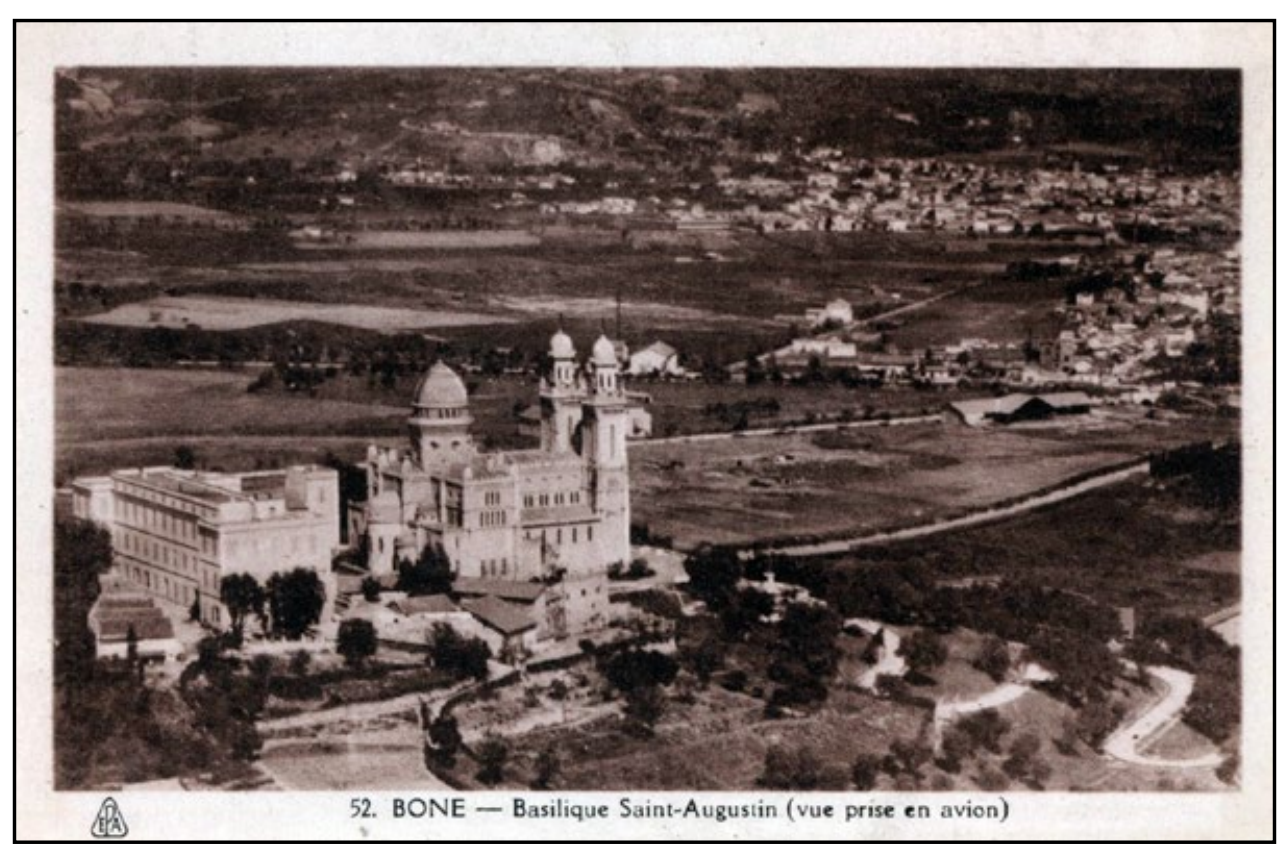

P1. 23. Aerial view of the Basilica of St. Augustine. Bone, Algeria. Black and white postcard from the estate of Sid Wolf. National Museum - Náprstek Museum, ethnographic photographic collection, Af III 904. 